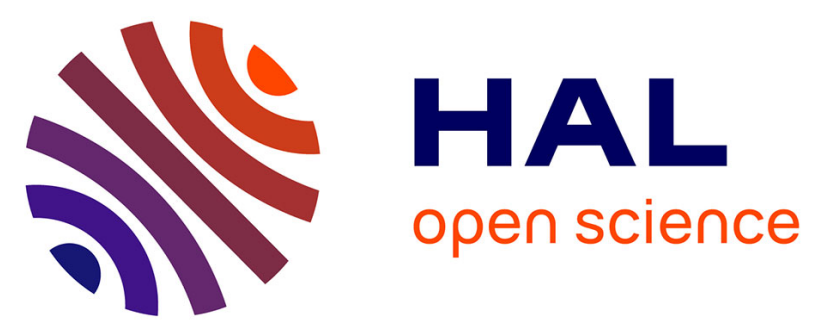

\title{
INTERROGATING THE TOURISM INDUSTRY OF BENUE STATE: THE PAST AND PRESENT OF MAKURDI ZOOLOGICAL GARDEN AND IKYOGEN CATTLE RANCH, BENUE STATE, NIGERIA
}

\author{
Terngu S Nomishan, Oryina J Andzenge, Igbalumun Aarga
}

\section{To cite this version:}

Terngu S Nomishan, Oryina J Andzenge, Igbalumun Aarga. INTERROGATING THE TOURISM INDUSTRY OF BENUE STATE: THE PAST AND PRESENT OF MAKURDI ZOOLOGICAL GARDEN AND IKYOGEN CATTLE RANCH, BENUE STATE, NIGERIA. Journal of Tourism and Heritage Studies, 2020, 9 (1), 10.33281/JTHS20129.2020.1.1 . hal-03548335

\section{HAL Id: hal-03548335 \\ https://hal.science/hal-03548335}

Submitted on 30 Jan 2022

HAL is a multi-disciplinary open access archive for the deposit and dissemination of scientific research documents, whether they are published or not. The documents may come from teaching and research institutions in France or abroad, or from public or private research centers.
L'archive ouverte pluridisciplinaire HAL, est destinée au dépôt et à la diffusion de documents scientifiques de niveau recherche, publiés ou non, émanant des établissements d'enseignement et de recherche français ou étrangers, des laboratoires publics ou privés. 


\title{
INTERROGATING THE TOURISM INDUSTRY OF BENUE STATE: THE PAST AND PRESENT OF MAKURDI ZOOLOGICAL GARDEN AND IKYOGEN CATTLE RANCH, BENUE STATE, NIGERIA
}

\section{Terngu S. Nomishan}

Department of Archaeology and Museum Studies,

Federal University Lokoja,

Kogi State, Nigeria.

Corresponding Author: terngu.nomishan@fulokoja.edu.ng

DOI: https:// doi.org/10.33281/JTHS20129.2020.1.1

\section{Oryina J. Andzenge}

Department of Public Administration,

Akawe Torkula College of Advanced and Professional Studies, Makurdi, Benue State, Nigeria.

\section{Igbalumun Aarga}

Department of Archaeology,

Ahmadu Bello University,

Zaria-Nigeria.

\begin{abstract}
This paper presents an interrogation of the struggling Tourism Industry of Benue State, analysing the past and present states of Makurdi Zoological Garden and Ikyogen Cattle Ranch. The research is aimed at bringing out the untapped tourism potentials in Benue State and also promotes the reach cultural heritage of the Tiv people of Central Nigeria. Therefore, a purely exploratory research design, with qualitative instruments and review of relevant literatures on the subject matter were employed in eliciting data for the research. Thus, data gathered revealed gross negligence of the tourism sector in the State; evident in the present status of the Zoo and the Ranch. For example at Makurdi Zoological Garden, it was gathered that there has been dwindling funding of the Zoo, lack of facility maintenance and lack of staff welfare, which has resulted into the malnutrition and death of several animals in the Zoo amongst other problems. Also, similar issues were observed at the Ikyogen Cattle Ranch. The Ranch is presently abandoned and some structures put in place by the first Executive Governor of the State, Aper Aku in 1983 are deteriorating to an abysmal stage, while others have since collapsed. Consequently, this research highlights some of the problems that led to the destruction of the Zoo and the Ranch as well as the entire tourism sector of the State and suggests possible solutions to the problems. The research also outlines some recommendations for the revamping and further development of the Zoo/Ranch in particular and the Tourism Industry of the State in general, to harness its potentials for the economic wellbeing of the people and government of Benue State.
\end{abstract}

Keywords: Tourism Industry, Cultural Heritage, Interrogation, Makurdi Zoological Garden, Ikyogen Cattle Ranch, Benue. 


\section{Introduction}

Tourism, in its simplified form, represents the temporal movement of people to a place or surrounding outside their normal place of work and residence for obvious reasons; this considers tourism in terms of a migration at a particular point in time, it could involve the community in promoting tourism, the promotion and protection of natural things like plants and animals among others (Uwen, 2006 cited from Ogidi, 2015).

Tourism also means travel for recreational or leisure purposes. While a tourist is a person who travel to and stay in places outside his usual environment for not more than one consecutive year for leisure, business and other purposes and not related to the exercise of an activity remunerated from within the place visited (Okonkwo and Ikegwu, 2013). It is the act and process of spending time away from home in pursuance of recreation, relaxation, and pleasure, while making use of the commercial provision of services. Tourism has become a popular global leisure activity with a record of over 903 million international tourist arrivals in 2007; and with a growth of $6.6 \%$ as compared to 2006. Thus, international tourist receipts reached 856 billion in 2007 (WTO, 2008 cited from Okonkwo and Ikegwu, 2013).

As rightly argued by Okonkwo and Ikegwu (2013), there are three types of tourism that can be identified when using geographical movement, these include;

i. Domestic Tourism, which involves the movement of tourist within their country for tourism purposes such as leisure, business, visiting friends and relations (VFR), culture, health purposes among others.

ii. Regional Tourism, which is a movement of tourists within a given sub-region for tourism purposes listed above; and for a period of twenty-four hours and above.

iii. International Tourism, which involves movement of people from their country of origin/residence to another country for specific tourism purpose(s). Apart from these, the intents and purpose of travel are often used to categorize tourism; thus, tourist who travel for cultural purpose could be referred to as cultural tourist/tourism, for the love of nature (eco-based tourism), for sport purpose (sport tourism), for religious purpose (faith/religious tourism) and for knowledge seeking (educational tourism) among others.

Tourism as an industry is dynamic and competitive, and is recognized widely as one of the world's largest growing industry. According to the Travel Industry Association (TIA), tourism accounts for $\$ 740$ billion in direct travel expenditures by both domestic and international travellers. International travellers to the United States of America spend $\$ 107.9$ billion every year. Outside the U.S.A., Americans spend $\$ 99.6$ billion on tourism, creating an $\$ 8.3$ billion U.S.A. trade surplus in the sector. Tourism provides $\$ 110$ billion in tax 
revenue for Federal, State, and Local Governments. In terms of direct spending by residents and international travellers, the TIA estimates $\$ 2$ billion per day is spent in the U.S.A. on travel-related items. The average overseas visitor to the U.S.A. spends $\$ 1,647$, with average trip duration of five to six nights (Nejdet, 2010).

Additionally, the tourism industry is one of America's largest employers, providing $\$ 7.9$ million jobs and spending $\$ 178$ billion in direct travel-related payroll (The Travel Industry Association (TIA), Facts and Information). But the travel and tourism industry is exceedingly complex. In fact, it has been called the "industry of industries," in recognition of the fact that travel-related firms range in size from multinational enterprises operating out of high-rise towers to individuals selling travel products and services from their homes. Furthermore, the tourism industry still faces the challenge of cautious consumers due to current economic, social, and political realities (Nejdet, 2010).

Tourism has made a lot of positive impact on many countries around the world; in creating conducive environments for tourists to visit such destinations and by so doing, it has promoted avenues for revenue generation in such countries where it serves as foreign exchange. Countries such as Israel, Malaysia, Singapore, UAE, China, USA, Britain, France, South Africa, Uganda, and Kenya are all tourist destinations (Anunobi and Egere, 2017). They are driven by the development of such environments where tourists tend to visit for holidays; to many organizations, they use such places as environments where they can host both local and international conferences (Terwase, et al. 2015).

Tourism activities around the world therefore promote interpersonal relationships among people, and the development of such relationships which serve as an avenue for peace and unity, as well as the results derived from the economic point of view from such relationships. Tourism Industry in Nigeria centres largely on events, due to the country's ample amount of ethnic groups, but also includes rain forests, savannah, waterfalls, and other natural attractions and recently archaeological/historical sites such as Nok, Sukur, Ele Ife, and Igbo Ukwu amongst others.

The World Travel and Tourism Council estimated that revenue related to tourism and travel in Nigeria will exceed \$1 billion USD in 2007, and will account for approximately $6 \%$ of the gross domestic product. Abuja is home to several parks and green areas with the largest one being Millennium Park. However, the industry suffers from the country's poor electricity, roads, and water quality. Another factor to consider is lack of political will on the side of government and the poor maintenance culture in the country that has deteriorated even the well-established tourist's attractions in Nigeria. This present ugly scenario is particularly evident in the tourism industry of Benue State. 


\section{Research Objectives}

The primary focus of the research is to bring out the present situation of the tourism sector of Benue State through the study of Makurdi Zoological Garden and the Ikyogen Cattle Ranch. The research highlights the causes that have led to the collapse of the sector in the State, suggests possible solutions and enumerates benefits of reviving/developing the sector to the people and government of the State.

Thus, it is pertinent to mention that there has been drastic decline in the percentage of tourist visitation to Benue State owing to the negligence of the sector by the government and other stakeholders. Consequently, several tourist attractions in the State have since escape public notice. For example, Makurdi Zoological Garden is located in the State Capital, however about 65\% of the occupants of the capital town cannot clearly describe the location, achievements, and present status of the Zoo. This is because the Zoo is totally neglected such that even structures initially put in place for the development of the Zoo are collapsing. Other cultural and natural attractions around the Zoo like the banks of River Benue and the shores of the river that would have been developed into a beach for leisure purposes are totally out of cognition.

Furthermore, Ikyogen Cattle Ranch is located within a large expanse of sprawling hills which present a fascinating sight to all visitors. The area is endowed with natural beauty which includes hills, a unique water falls, evergreen vegetation and a temperate weather. The Ikyogen hills and other hills located in the South-eastern part of Tivland surrounding the Ranch, are home to the reach cultural heritage of the Tiv people that demand none negotiable preservation for future generations. These hills include the Ushongo, Ikyogen, Ibinda, Bako, Kpe, Ngokugh, Akovurwo, Ikyo, Akoo, and Dajo hills, amongst others. Other attractions also found around this location include rainforests, waterfalls, dykes, incised valleys and several other archaeological sites that would have been managed by the Cultural Heritage Management department of the Ikyogen Cattle Ranch.

Therefore, this research seeks to create awareness amongst the stakeholders and the general public to expedite actions towards revamping the sector for the overall wellbeing of the State and its people.

\section{Research Methodology}

This research being a qualitative one, elicited data through field survey

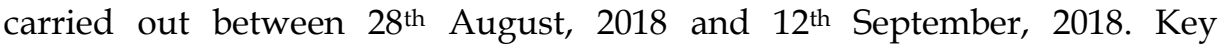
Informant Interview method was used in eliciting data for the research. Thus, a wide range of informants including community leaders, professionals and other residents who had knowledge about the beginning, development and challenges of tourism sector in Benue State and associated attractions under study were interviewed. A total of 18 informants comprising men and women at the age range of 18 to 70 years were selected and interviewed using structured and unstructured question guide. 
More so, survey instruments like the Global Positioning System (G.P.S.) receiver, digital camera, and tape recorder were used to acquire geographical positions of essential features/areas studied; take photographs of important features, objects as well as animals; and audio tape some informants responding to vital issues if necessary. Thus, the researcher asked questions regarding particular issues and the informants provided answers in a narrative form. Meanwhile all the data were recorded in a notebook, stored in a camera and sometimes stored in an audio recorder. The research also made use of secondary data to confirm as well as support the research findings for a logical conclusion.

\section{Background Information on Benue State}

Benue State was created on the $3^{\text {rd }}$ February, 1976. It was amongst the seven new States created by the military administration headed by late General Murtala Muhammed, which increased the number of States in the Federation from twelve to nineteen. The name "Benue" was derived from River Benue; the second largest river in the country.

Benue State is located within the lower River Benue trough in the Middle Belt Region of Nigeria. The State shares boundaries with six other States. These include Nasarawa to the North, Taraba to the East, Kogi/Enugu to the West and Ebonyi/Cross-River to the South respectively (see figure 1 below). The State also shares an international boundary with the Republic of Cameroon on the South-eastern part of the State. Also, the State occupies a landmass of 33,955 square kilometres. It is situated within a geographical position of $6.5^{\circ}$ to $8.5^{\circ} \mathrm{N}$ and 7.470 to $10^{\circ} \mathrm{E}$.

More so, going with the Köppen Climate Classification, Benue State lies within the tropical savannah climate. The State experiences two distinct climatic seasons, the wet and dry seasons. The wet season lasts from April to October, with annual rainfall ranging from 1000 to $1500 \mathrm{~mm}$. The dry season begins in November and ends in March. The annual temperatures in the State fluctuate between $21^{\circ} \mathrm{C}$ to $37^{\circ} \mathrm{C}$, with the South-eastern part of the State adjoining the Obudu-Cameroon mountain range, having cooler climate conditions similar to those of Jos Plateau. 


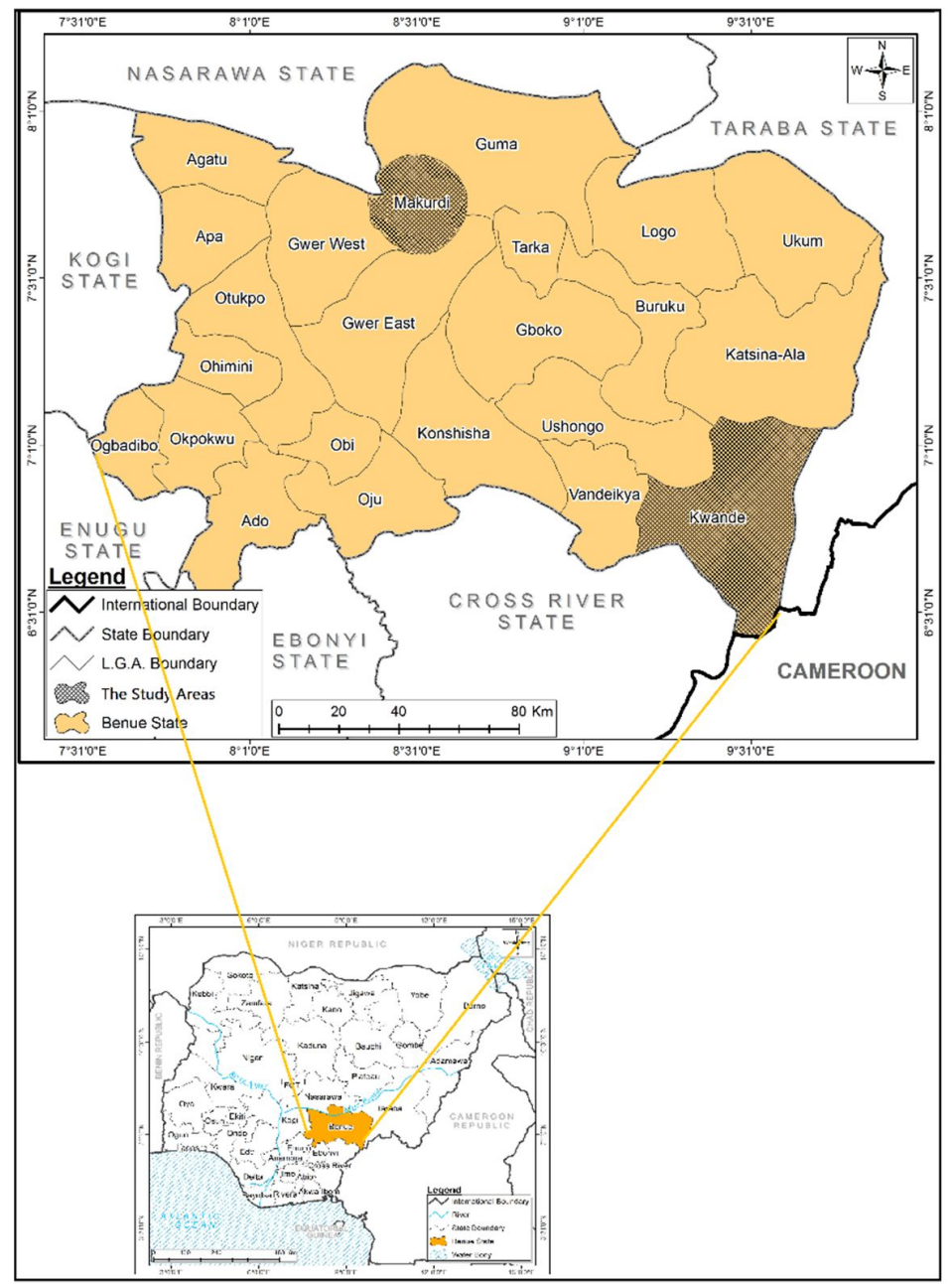

Figure 1: Map of Benue State showing Makurdi and Kwande L.G.As.

Source: Map Gallery, Geography Department, ABU Zaria

\section{Presentation of Findings}

Findings in the research comprised of information from oral history concerning the beginning/development of tourism activities in Benue State, the periods of the establishment, subsequent development/achievements and challenges of Makurdi Zoological Garden and Ikyogen Cattle Ranch respectively. The data gathered enabled the authors to identify the problems facing the tourism sector/associated attractions like the Zoo and the Ranch, suggest possible solutions and highlights some benefits of revamping the sector and its institutions to the State as given below.

\section{Tourism Industry of Benue State}

Benue State has a wide range of tourist attractions. The State has tourism potentials which include its numerous archaeological sites on hills 
(e.g. Ikyogen, Ibinda, Bako, Kpe, Ngokugh, Akovurwo, Ikyo, Akoo, Dajo, Ushongo, and Gboko amongst others), rain forests, water falls, and other natural attractions. Most of these tourism attractions are not developed. Even the few that have seen some level of development are presently undergoing deterioration due to negligence.

This adamant nature of the state government and other stakeholders towards the development of existing tourism attractions in the state and maintenance as well as expansion of already developed ones like the Makurdi Zoological Garden and the Ikyogen Cattle Ranch, has pitched the local communities living in the affected tourism attractions against the State Government, the Local Government Councils and wealthy citizens of the State. This has also resulted in massive looting of already installed equipment and structures in the tourism attractions, making them more vulnerable to destruction. In this paper, emphasis is on two known tourist attractions in the State that are undergoing the highest level of negligence. They include, Makurdi Zoological Garden and Ikyogen Cattle Ranch.

\section{The Makurdi Zoological Garden}

The Makurdi Zoological garden is situated in the Eastern part of Makurdi town in the Guinea Savannah zone of the town. It is on the Southern bank of River Benue and 1.5 kilometers along Makurdi-Gboko express way. It is also half a kilometer off Makurdi-Gboko road into the premises of the Benue State University (see plate 1 ). It covers about $0.32 \mathrm{~km}^{2}$ of land (Uloko and Iwar, 2011).

During a visit to the Garden on 28 $8^{\text {th }}$ September, 2018, the authors observed that Makurdi Zoological Garden was in a deplorable condition. Almost all the facilities in the Garden were dilapidated. Even some of them that still have some animals kept in them were deteriorating at an alarming rate. Consequently, the bad condition of the Garden that has resulted from total negligence of the Garden by successive administrations in the State has led to the death of almost all the animals that were earlier kept in it. The few ones still battling with life in the Garden as at the time of this research were seen suffering from malnutrition, deplorable environment of the Garden and lack of medical attention amongst other issues.

This situation has made the Garden to be forgotten by even the residents of Makurdi town. Also, majority of the Benue State University students who lives in the same environment with the Garden are unaware if the Garden is still in existence. For example, a lion, a lioness and a cheetah were seen lying down presumably due to hunger in the Zoo. Like the other animals in the Zoo, these wild animals all had their ribs shooting out, making them look like carcasses behind those rusty bars that have held them hostage for man's entertainment. 

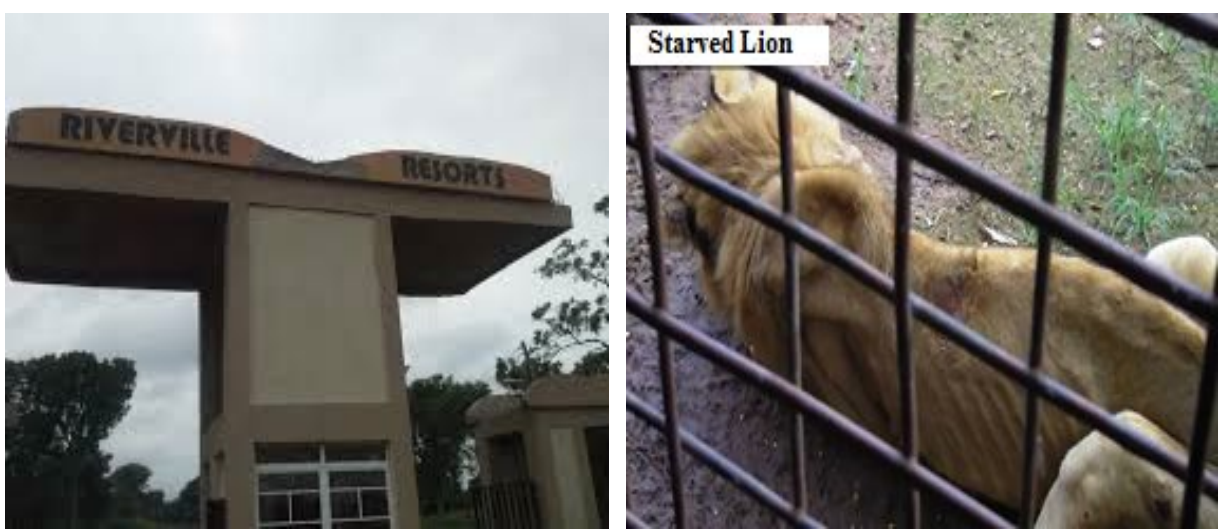

Plate 1: Makurdi Zoological Garden

Plate 2: A Lion Suffering from malnutrition

Seemingly, the lack of maintenance culture of the Benue State Government is well exemplified on the Makurdi Zoological Garden. All the structures in the garden are not worthy of use; some has already collapsed while some are better seen as abandoned structures. The few Staff working in the Zoo also suffers poor welfare which has made them to lose motivation to duty.

\section{The Ikyogen Cattle Ranch}

The Ikyogen Cattle Ranch is located about 35 kilometres East of Adikpo, the Kwande Local Government Area Headquarters. The Ranch is located within a large expanse of sprawling hills which present a fascinating sight to all visitors. The area is endowed with natural beauty which includes hills, a unique waterfall, evergreen vegetation and a temperate weather. The hills environment maintains the lush green vegetation that makes it a favourite spot for animal grazing. The place provides a good blend of adventure and sightseeing and because of the unique environment; it is capable of receiving visitors at any season of the year.

The Ikyogen Cattle Ranch was first developed for cattle grazing on the highlands and modelled after the Obudu Cattle Ranch in Cross River State by the first Executive Governor of Benue State, Mr Apolos Aper Aku in 1983. The Ranch was therefore put to use why there were still plans to complete construction works on the site and put it on the gallery of world best ranches.

However, things had since changed as successive administrations in Benue State have abandoned this visionary project. Consequently, the crumbling pillars hoisting an iron signpost that is now rusted with inscription "Benue Cattle Ranch Ikyogen" appears to be the only vestige of what used to be a thriving Ranch, which had hundreds of cattle grazing the green plains of the undulating Ikyogen hills (see plate 3 ). 


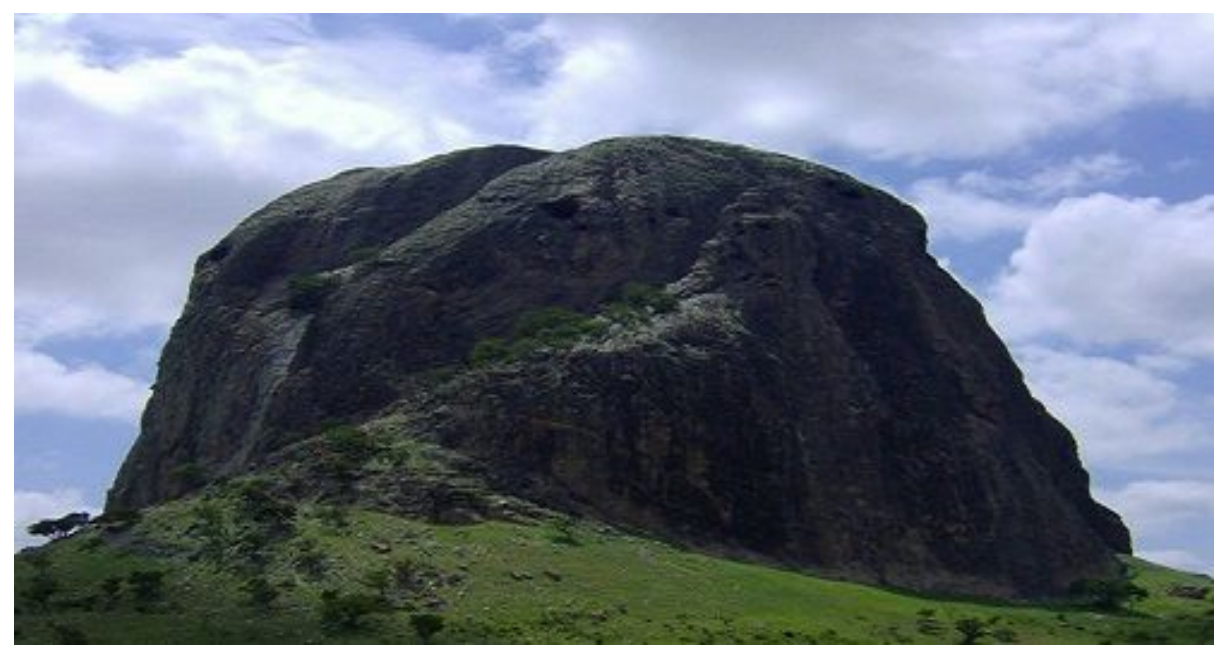

Plate 3: The Ikyogen Hills.

Consequently, all proposed projects for the development of the Ranch are since abandoned. Projects such as the development of all the natural attractions in the Southern part of the State and development of the reach archaeological sites in and around the Ranch, that constitutes the reach cultural heritage of the Tiv people, for cultural tourism that would have been managed by the Cultural Heritage Management Department of the Ranch, to boost tourism activities in the area has been totally abandoned.

\section{Benefits of Developing these Tourism Attractions to Benue State}

There exist diverse opportunities in developing a community with potential of becoming a tourist destination. One of the greatest benefits of this is the fact that the community becomes extremely labour intensive, having micro business operators within it. This means that any money coming into the industry is felt quickly by business owners, staff, and the community in general, which is directly a boost to the local economy.

Another dimension in which tourism industry have proven significantly in community development is in the area of travel arrivals. Tourism industry is one of the largest and fastest growing sectors in the world, with economic growth in 2017 of $4.6 \%$ and GDP growth of 50\% higher than that of the global economy (Sofronov, 2018, p. 125).

According to Sofronov (2018, p. 125) "in 2017, there were 1.322 billion international tourist arrivals; an increase of $7 \%$ compared to the previous year, and the strongest growth rate for seven years. By 2030, it is estimated that there will be 1.8 billion international tourist arrivals, which means an average of 5 million people crossing international borders every single day".

This can become the fortune of Makurdi Zoological Garden and Ikyogen Cattle Ranch. All these areas have great tourism potentials that have been wasted for centuries. For example, Makurdi Zoological Garden can singularly open up the coastal areas of River Benue, at least those around 
Makurdi town. Beginning as a zoo, the garden can become a popular tourist attraction with such necessary demands of markets, leisure places, restaurants, hospitals and accommodation facilities amongst others.

In the same vein, Ikyogen Cattle Ranch has every potential to become one of the world best tourist attractions. The environment of the ranch is often likened to (if not rated above) those of Jos Plateau and Obudu Cattle Ranch. As stated earlier, the hills of Ikyogen maintains the lush green vegetation that provides a good blend of adventure and sightseeing. Thus, if developed (in the initial plan of the 1980s visionaries), the ranch has a great promise of receiving visitors at any season of the year owing to its unique environment. Also, the numerous archaeological sites in and around the Ranch have the potentials of inviting researchers, teachers, students, and other visitors to the Ranch. Some of the benefits of revamping the Makurdi Zoological Garden, the Ikyogen Cattle Ranch, and the entire tourism sector, to Benue State and its environs include but not limited to the following:

1. Employment Potentials: One of the easiest advantages to identify is the huge benefit of job creation. This range from directly influenced positions like tour guides, hotel staff, coach services, and restaurants. These businesses in addition to providing the needed funds for the payment of wages to their staff, also source goods and products locally, giving a boost to local industry. In the year 2017, tourism industry employed 313 million people across the world, equivalent to 1 in 10 jobs, and generated $10.4 \%$ of global gross domestic product (GDP) (ICAO, 2018, cited from, Sofronov, 2018, p. 125).

Additionally, development of these tourist attractions can benefit the people and government of Benue State in the support of retail trade and food production in communities around them. Thereby, creating a lot of job opportunities in such areas and beyond. Therefore, Benue State can stand the chance of creating hundreds (if not thousands) of job opportunities for its citizens through the development of Makurdi Zoological Garden, Ikyogen Cattle Ranch and other notable attractions in the state to standard tourist attractions.

2. Increase in the Economy of the Local Community: This comes in two directions (a) there is money spent directly by tourist in the economy of the community, (b) there is also money spent on huge range of other basic human requirements of tourist, like food, clothing, hairdressing, medical services, transportation needs, provision of souvenirs and amusements amongst others. This of course can establish a unique trading chain within and around the state.

3. Economic Diversification: In addition to bringing prosperity to the economy of the host communities and the State at large, development of the tourism sector and its institutions can also grow the economy of the State and increase internally generated revenue of the State. There will be no concentration on one product or service. The demand that will be brought about by tourist in these areas would force the 
discovery of new means of production and enhance the revamping of many abandoned means of livelihood in the State.

Development of Makurdi Zoological Garden and Ikyogen Cattle Ranch to standard tourist attractions will not only bring about the establishment of waste recycling industry, but it will also promote proper waste management in the State and beyond. For example, yam, cassava and potatoes peels amongst others will be processed into animal feeds and so on.

4. Infrastructural Development: The additional revenue that will come into the host communities will also benefits the Local Government Councils or the State Government. This means that development of these key areas can improve infrastructural condition of the State to a large extent. This will promote construction of new roads, parks, and public spaces amongst others. The better the facilities, the more visitors are attracted to a tourist attraction. Fantastic benefits will accrue to the local residents, as there will be enough revenue to build new schools, hospitals, markets, worship centres and even air ports in the State. This is because without good infrastructural development, the free flow of goods and services to boost the businesses and present opportunities for new ones will be far-fetched.

5. Cultural and Social advantages: In addition to the revenue, there also exist cultural advantages in tourism development. This can promote patriotism amongst members of the host communities and increase the zeal to study their history, which also influences preservation and protection of their cultural heritage. As different people from diverse parts of the world visit the communities regularly, the communities become popular and their identity gets promoted.

The people will be more patriotic and strive to maintain their traditions and culture, while also showcasing it to the visitors. This factor of tourism has saved many local heritage sites from destruction, in addition to giving tourist a wonderful insight into their local ways of life. Thus, Ikyogen Cattle Ranch can be developed to form the avenue through which all the archaeological sites of the Tiv people located in the South-eastern Tivland and extensively studied by several professionals can be protected and preserved for future generations (see Folorunso, 1981; Tubosun, 1981, 1995; Tubosun and Andah, 1983; Ogundele, 1993; Gundu, 1999; Ndera, 2009, 2013; Chia, 2014; and Nomishan, 2014).

6. Environmental Advantages: To fulfil best tourism practices, tourism operators contribute to the protection of the environment from which they operate by way of developing and maintaining the environment at all times. They support the conservation of the local area and provide basic social amenities to the host communities. This helps both the environment in dealing with the influx of tourist, and also builds a strong reputation for the tourism operators. 
Tourists on their own part are always advised to respect the tour areas they visit, and always leave them as or better than how they met them. Thus, if developed, tourism sector will become a contributor to the environmental management strides of Benue State.

7. Tourists bring Global Standards: Tourists being global customers creates strong needs of global standards in services and infrastructure. As people from diverse locations of the world visit the area, they bring different standards that are gradually being accepted by the indigenous people. Certain knowledge is brought into the community by tourist, thereby contributing in improving the ways of doing things in the local community.

Consequently, Benue State being an agrarian state can become one of the best industrialized areas of the world having accepted such standards in production and processing of food amongst other things.

8. Tourism Induces High Consumption: Since tourists do not go about with consumables, there exist high demand for goods and services in tourism destinations. This is because the more the visitors that come into the area, the more the rate of consumers, thereby creating great demand for goods, products and services. Thus, if Makurdi Zoological Garden, Ikyogen Cattle Ranch and other tourist attractions in the State are developed into standard tourism destinations, they will also create high patronage of foods like yam, cassava, potatoes, rice, and orange amongst other food items that are produced in commercial proportions in the State.

Therefore, it is worthy of note that the advantages of developing the tourism sector and attractions in the State far outweigh its disadvantages such as, occurrence of changes in the culture and/or other ways of life of citizens of the host communities, increase in cost of living, high wages and over population amongst others. This is because all these demerits can be curtailed through proper planning and regular supervision, to ensure accurate implementation, for the maintenance of law and order, surplus of goods and services, and promotes cultural practices in the host communities and the State at large.

\section{Conclusion}

Following the above analysis, it is understood that tourism brings people from everywhere in the world. It connects places with people; places with places; and people with people. This sector brings the developed, developing and even the underdeveloped or emerging economies to a reasonable state of recognition. Thus, empowering them to become competitive globally and improve on their level of products and services.

More so, seeing the poor state of virtually every sector in the State at the moment, it is paramount to state here that there should be a change in the lackadaisical attitude of the government and wealthy Benue entrepreneurs 
towards tourism industry in the State. Tourism attractions in the State such as Dajo Pottery, Anwase-Abande Ranges, Ikwe Holiday Resort, Enemabia Warm Spring, Montane Games Reserve, Katsina-Ala Rare Manatee and the popular archaeological Hills hosting the reach cultural heritage of the Tiv people, are left without development. Even the ones that were earlier recognized in the 1980s have been abandoned and are into unimaginable deterioration as exposed in the study of Makurdi Zoological Garden and Ikyogen Cattle Ranch.

Therefore, this analysis has brought out the unimaginable benefits that await the development of the tourism sector and attractions in the State. Thus, this research is also an awakening call on the State Government and all the stakeholders in the tourism industry to expedite actions toward the implementation of the recommendations in this research.

\section{Recommendations}

The authors recommend that the government and people of Benue State should work towards revamping the already existing tourist attractions such as the Makurdi Zoological Garden and the Ikyogen Cattle Ranch amongst others. Efforts should also be made towards researching, preserving and promoting the reach cultural heritage of the ethnic groups in the State so as to boost cultural tourism in the State. More so, all the viable natural attractions in the State should be developed, maintained and preserved for the benefit of future generations. Thus, if relevant stakeholders expedite actions towards implementation of these recommendations, problems of hunger, unemployment, social vices, and the general underdevelopment in Benue State will be greatly curtailed.

\section{References}

Anunobi, H. N., \& Egere, C. A. (2017). Developing a Vibrant Tourism Industry in Southeast Region of Nigeria. Journal of Tourism and Heritage Studies, $6(2), 25-42$.

Chia, C. T. (2014). Archaeological Survey of Gbanger and Mto Hills in the Hiitom Area of Ushongo Local Government, Benue State, Nigeria. Unpublished M.A Thesis, ABU Zaria.

Folorunso, C. A. (1981). The Prehistoric Settlements of the Tse Dura and Ushongo Hills: A Preliminary Study. M.Sc Thesis, University of Ibadan.

Gundu, Z. A. (1999) Historical Archaeology of Ancient Settlements in South Eastern Tivland, Benue State, Nigeria. Ph.D. Thesis. University of Ibadan, Ibadan

ICAO, (2018). Travel and Tourism a Force for Good in the World. Accessed November https://www.icao.int/Meetings/iwaf2018/Documents/Travel\%20an d\%20Tourism.pdf 
Ndera, J. D. (2009). Archaeological Investigation of the Early Settlements of the Shitire in the Benue Valley of Nigeria. Unpublished Ph.D Thesis, University of Ibadan.

Ndera, J. D. (2013). Archaeological Perspectives on the Origins and Migrations of the Tiv in the Benue Valley of Nigeria. Journal of Tourism and Heritage Studies, 2(2), 14-23.

Nejdet, D. (2010). Current trends in the global tourism industry: evidence from the United States. In Rap - Rio De Janeiro, 44(5), 125-137.

Nomishan, T. S. (2014). An Archaeological Reconnaissance Of Kpe Hill-top Settlement Site In Mbaikya Community, Usambe District Of Kwande Local Government Area Of Benue State, Nigeria. Unpublished B.A. Thesis, A.B.U Zaria.

Ogidi, A. E., \& Tondo, D. T. (2015). Weaving Through Paradoxes of Agritourism and Commodificaiton in Nigeria: Benue State Vs Cross River State Comparison. ARC Journal of Academic Research (ARC-JAR), 1(1), 39-50.

Ogundele, S. O. (1993). Archaeological Reconnaissance and Excavation in Parts of Tivland. West African Journal of Archaeology (WAJA), 23, 67-91.

Okonkwo, E. E., \& Ikegwu, U. J. (2013). The Career Prospects of Tourism in Nigeria. Research on Humanities and Social Sciences, 3(12), 126-132.

Sofronov, B. (2018). The Development of the Travel and Tourism Industry in the World. Annals of Spiru Haret University. Economic Series, 18(4), 123137. http:// doi.org/10.26458/1848.

Terwase, I. T., Abdul-Talib, A., Edogbanya, A., Zengeni, K. T., Yerima, H. M., \& Ibrahim, M. B. (2015). Obudu Cattle Ranch: A Tourist Destination in Nigeria. Research on Humanities and Social Sciences, 5 (20), 67-71.

Tubosun, B. J., \& Andah, B. W. (1983). Sedimentological Analysis of Tse-Dura Prehistoric Rock shelter Deposits. West African Journal of Archaeology, 13, 6172.

Tubosun, B. J. (1981). Geo-Archaeology: Tse-Dura Prehistoric Rock shelters (Benue State of Nigeria) as a case study. Unpublished M.Sc. Dissertation, University of Ibadan.

Uloko, I. J., \& Iwar, M. I. (2011). Impact of Makurdi Zoological Garden and Manaterium on Conservation Education in Benue State. Journal of Research in Forestry, Wildlife and Environment, 3(2), 24-31. 